\title{
Abordagem
}

\section{Avaliação na Universidade}

\section{José Goldemberg}

O problema de avaliar professores, departamentos, faculdades e a própria Universidade exerce uma estranha fascinação nos meios de comunicação do País, bem como nos próprios avaliados.

Uma questão que deveria ser tratada com a maior naturalidade provoca as mais desencontradas reaçōes emocionais. Afinal de contas, professores das universidades públicas brasileiras são funcionários públicos e deveriam ser avaliados como o são (ou deveriam ser) os demais funcionários. Mais ainda, tratandose de instituiçōes a serviço da comunidade e sustentadas por ela, deveria ser obrigatório haver uma fiscalização efetiva para saber se elas estāo cumprindo seu dever.

Curiosamente, um certo número de professores, sobretudo os mais jovens e iniciantes na carreira universitária, resistem a qualquer tipo de avaliação que não seja corporativista, isto é, feita por eles mesmos. A ênfase em processos democráticos de avaliação, transparência completa, avaliação com participação ampla dos departamentos (e possivelmente plenárias, em alguns casos) ou auto-avaliação são instrumentos retóricos para evitar uma avaliação séria. Há, nestas propostas, um componente intrínseco de negação de qualquer hierarquia do saber e da vida universitária. A idéia de que os mais sábios e mais experientes são os juízes do trabalho dos iniciantes é, no fundo, combatida e o uso de avaliadores externos à instituição é abominado. Felizmente, a promoção na Universidade de São Paulo só é feita através de concursos públicos onde a presença de examinadores externos é obrigatória; sucede que feitos todos os concursos, cessaria, na prática, qualquer avaliação. É por isso que, sabiamente, o novo Estatuto da USP determina que todos os docentes serāo avaliados a cada 5 anos.

A imprensa em geral e os militantes de grupos progressistas sempre defenderam a transparência e a prestação de contas dos funcionários públicos, como mostra a popularidade das listas de marajás publicadas na imprensa dentro e fora da Universidade. Grupos mais conservadores partilham destas visões moralistas e um dos atuais candidatos à Presidência da República conquistou notoriedade nacional com a caça aos marajás no seu Estado. Nestas ocasiōes, o direito à privacidade e outros princípios éticos não foram invocados; a idéia era de fato execrar os funcionários e/ou professores mais bem remunerados.

Esta veia profundamenle moralista - talvez pequeno-burguesa - tem raízes profundas na sociedade brasileira, provavelmente como uma reação à concepção, arrogância e inépcia dos servidores do Estado. É de se notar, contudo, que um representante de um dos partidos progressistas (PT) ao assumir a Presi- 
dência da Câmara Municipal recusou-se a divulgar a relação dos funcionários com seus salários, alegando que representaria quebra de privacidade.

A publicaçăo de listas tem uma velha história. Em 1781, nove anos antes da Revolução Francesa, Necker, um dos ministros de Luís XIV, foi obrigado a pedir demissão por ter publicado a lista dos cortesăos do Rei com os subsídios que recebiam; o escândalo foi provocado pelos atingidos e não pela população que, pela primeira vez, teve acesso aos privilégios dos beneficiários do Poder.

É por essas razōes que não entendemos o pudor exagerado e ate a indignaçäo de alguns professores que se consideram atingidos na sua privacidade $e$ dignidade por serem avaliados por instrumentos objetivos e não apenas pelos seus companheiros. A avaliaçāo pelos pares é usual em ciência, mas por pares se entendem cientistas da mesma área (ou área afim) não da mesma instituiçăo ou do mesmo grupo.

Ela não tem caráter persecutório, mas estabelece uma hierarquia de competência e serve de instrumento para alocação de recursos, como qualquer professor que tenha solicitado uma bolsa de estudos ou um auxilio para pesquisas sabe muito bem. $O$ resto $e$ farisaísmo.

É por estas razōes que a Universidade de São Paulo está aperfeiçoando os instrumentos de avaliaçáo do seu corpo de professores, funcionários e estudantes, como é obrigaçăo de toda instituição pública.

Poder-se-ia perguntar se os mecanismos atuais não bastam para eliminar estes problemas, mesmo porque a formação de professores só se faz por concurso, que dá uma excelente oportunidade para aprovar uns e reprovar outros.

$\mathrm{O}$ artigo 104, incluído no Estatuto, indica que o $\mathrm{CO}$ acredita que a resposta a esta pergunta é negativa e deseja que o Regimento Geral introduza novos mecanismos de avaliaçāo.

Uma razão óbvia para introduzir novos mecanismos $\varepsilon$ a de que professores estáveis (e a maioria dos professores da USP está nesta condição) não são submetidos a renovaçōes de contrato e os titulares no grau máximo de carreira não se submetem a qualquer concurso adicional para promoção.

Além disso, a experiência mostra que no caso de concursos de promoçäo são muito raras as reprovaçöes e que as bancas são organizadas de forma a serem extremamente lenientes.

Daí a necessidade de critérios gerais estabelecidos no Regimento Geral da Universidade e que balizarão os procedimentos de cada Unidade. É natural que as reavaliaçöes devam se proceder nas unidades (Conselhos de Departamentos e Congregaçōes) onde se encontram os pares dos professores avaliados. É claro, tambem, que estas reavaliaçöes não podem se esgotar neste nível para evitar compadrismo; É para evitar isto que bancas de concurso sempre têm examinadores externos à Unidade. Além disso, um departamento medíocre tenderá à paz interna quando a melhoria do nível da Universidade puder exigir exatamente que esta paz interna seja perturbada pela presença de especialistas externos aos departamentos.

Jose Goldemberg é Reitor da USP. 